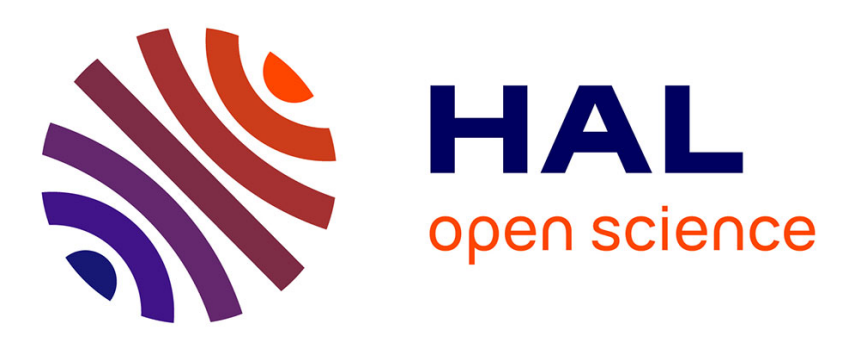

\title{
Antecedents of Sustainable Vocational Education and Training in ICT in Global South Countries
}

\author{
Javier Osorio, Julia Nieves
}

\section{To cite this version:}

Javier Osorio, Julia Nieves. Antecedents of Sustainable Vocational Education and Training in ICT in Global South Countries. 1st International Conference on Sustainable ICT, Education, and Learning (SUZA), Apr 2019, Zanzibar, Tanzania. pp.157-166, 10.1007/978-3-030-28764-1_18 . hal-02515745

\section{HAL Id: hal-02515745 \\ https://hal.inria.fr/hal-02515745}

Submitted on 23 Mar 2020

HAL is a multi-disciplinary open access archive for the deposit and dissemination of scientific research documents, whether they are published or not. The documents may come from teaching and research institutions in France or abroad, or from public or private research centers.
L'archive ouverte pluridisciplinaire HAL, est destinée au dépôt et à la diffusion de documents scientifiques de niveau recherche, publiés ou non, émanant des établissements d'enseignement et de recherche français ou étrangers, des laboratoires publics ou privés. 


\title{
Antecedents of Sustainable Vocational Education and Training in ICT in Global South Countries
}

\author{
Javier Osorio and Julia Nieves \\ Universidad de Las Palmas de Gran Canaria, 35017, SPAIN \\ javier.osorio@ulpgc.es
}

\begin{abstract}
The topic of sustainability is another component of the complex issue of fostering effective vocational education and training (VET) initiatives in information and communication technologies (ICT) in Global South countries. There is no workable model of VET for Development, and simple, symptomatic solutions are no longer suitable. This paper attempts to summarize some drivers that can be considered as antecedents of this issue. They conform part of the big picture that arises when addressing long term, structural proposals. The prism of sustainability has been included as a complementary lens with which to look at it. Sustainability can serve to either shed some light on the issue or, alternatively, add some uncertainty and pressure, with the result of making it even more complex.
\end{abstract}

Keywords: Vocational education and training, VET, Information and communication technologies, ICT, Global South, Sustainability.

\section{Introduction}

The development of vocational education and training (VET) in many Global South countries is a complex issue. In fact, it is a complex issue all around the world, but in the case of low-income countries it faces additional challenges because of the lack of available educational and technological resources. The task of interpreting and unravelling the picture of all variables and circumstances that converge when designing and developing VET initiatives, especially in Global South countries, appears to be a difficult one. Analysis and recommended courses of action have been raised by national governments, regional organisations (Southern African Development Community - SADC, Union of South American Nations - USAN) and global institutions (OECD, UNESCO); often with the only result being that the big picture becomes even more complicated. The objective of this paper is to re-examine the issue of VET initiatives in Global South countries under the prism of sustainability which, as a general concept, can potentially influence it both internally and externally.

Most of the arguments for explaining the differences in educational development between the Northern and Southern hemispheres tended to focus on the endemic lack of resources allocated to the educational arena in Global South countries. Another 
reason has been the low level of social-economic development, which serves as a constraint to the virtuous loop that links educational and economic improvement. The mirror of the Global North -where no doubt arises when justifying the link between education and economic development as the key to success- may promote the view that the formulae that apparently fits well in one part of the world can also work equally well everywhere else. Within this landscape, during the last thirty years another agent has irrupted becoming a major protagonist: information and communication technologies (ICT). The nature of this actor, heavily demanding of huge investments for it to be incorporated into the educational arena, has been supposed to be both a source of opportunity that allows educational processes to be aligned in countries of both hemispheres and, at the same time, a threat because of the costly nature of technology. The acquisition of ICT may, eventually, permit resources that could be allocated to other social or economic initiatives to be deferred. However, some research has showed that the focus on technology is not a key driver in educational improvement [1], thus providing a way to challenge the globally accepted paradigm of technology as a key factor in educational improvement.

Because of the complexity of the problem, we advocate for continuing the research on the variables and topics involved, to the extent where most of the big picture can be depicted. Although knowing the global blueprint does not mean that a solution or set of solutions can be outlined, at least it can encourage one to avoid symptomatic, short-term solutions and seek for structural ones instead. The organisation of this paper follows the proceeding structure. The first section addresses some outstanding variables and their implications in VET development programmes. The second section addresses the issue of taking into consideration sustainability as a filter that can also influence VET development. The third section offers some examples of recommended courses of action proposed by researchers and institutions aligned with sustainability principles. The paper concludes with some final thoughts about the implications for sustainable vocational education and training in ICT in Global South countries.

\section{An Approach to the Big Picture}

An important number of papers and contributions dealing with the topic of VET in Global South countries address the issue from different but complementary perspectives, contributing towards shedding light on the problem. Most of them propose courses of action to face the issue and achieve better results. The general perception is that the task appears complex because of the high number of variables involved, and that single solutions are ineffective. Next, several of those variables are briefly described, without the pretence of being exhaustive.

\subsection{The information technology utopia}

[2] categorised the ambitious policy rhetoric contained within the launch of project documents by governmental bodies and international institutions as examples of the 
'magical properties' that policymakers attach to the new technologies in education, where the most extended assumption is that more technology equals more learning. The large number of newer and more resource-demanding initiatives that have arisen as part of the reform agendas to bring ITC into the educational setting seem to have become little more than a hardware distribution operation [3]. Despite more than two decades of research indicating the absence of any direct causal link between investment in education technology and improved learning outcomes, a remarkable number of policy statements from government officials still show their perception about the strong relationship between ICT and the quality of learning [4]. The political rhetoric does little to recognise that the relationship between technology and the classroom has always been a complex one. [5] highlighted the small amount of research that has taken place to investigate the relationship between ICT, classroom practice and learning outcomes. [1], in their analysis of ICT investment in schools in the USA and the impact upon student learning outcomes, have shown that no clear causal link exists between ICT investment and improved educational performance; indeed, their analysis confirms that socio-economic status (SES) has a far higher significance than connectivity and how many computers are in the classroom, even when equipment is available to students on a one-to-one basis. Some small overall student performance gain is evident in high-SES schools, but these gains are almost completely absent from low-SES schools, where other social and educational factors are of much more significance. [6], [7] and [8], have promoted an alternative view and commented on how idiosyncratic and dependent upon local conditions ICT implementation is. For instance, a UNESCO survey [9] acknowledged the small impact that ICT investment has had on education in the Middle East.

Across the world, governments have spent hundreds of millions of dollars on providing schools with ICT equipment and broadband connectivity [10]. The extent to which this significant investment is having any impact on innovative teaching and learning and the development of twenty-first-century skills is rather more limited. There is no automatic link between computers in the classroom and the development of the skills expected of an autonomous, self-directing learner. Another issue related to the generalised perception of technology as a central agent in education improvement is raised in low-resource environments, whereas the critical attitudes of teaching staff about technology development can, in turn, negatively influence the attitudes of recipients. In such environments, the complaints of teaching staff about the technology available locally, the electricity supply, the irregular connectivity, the bugs in their operating systems, or the age of their computers, can lead to a decrease in the amount of pride stakeholders take in their own resources [11].

There is an extant literature on ICT adoption that recognises availability and accessibility in developing countries as key factors. The literature reflects the efforts to promote the use of ICT in education in Global South countries as a component of the political will to modernise education, but funding continues to be, at large, a major constraint [12]. Since the late 1990s, based on private initiatives and sponsorships from non-governmental organisations (NGOs), several projects have aimed to equip schools with computer equipment (computers, video projectors and Internet access) and teacher training in the use of ICT. The situation among countries is different; for 
instance, [12] reports that visits to 46 educational institutions in the Republic of Burkina Faso and Democratic Republic of Congo, on their own, highlight the fact that certain states do not have sufficient resources to provide state schools with computer rooms. This situation contrasts with the evidence that only a few studies that focus on the impacts of ICT on national development that can inform ICT policy and decisionmaking in Africa exist [13].

\subsection{The complexity to develop effective institutions in Global South countries}

Although the neoliberal paradigm advocates for reducing as much as possible the intervention of public bodies in the economic and, even, the educational setting, a rather majoritarian consensus exists regarding the importance of institutions in promoting the development of their communities. Institutions symbolise the formal structures, informal rules and norms that govern the behaviour and expectations of different states [14]. The role of institutions in economic growth has been widely studied by researchers and has evolved over time. An institution often displays two sides of the same coin in the sense that it can either facilitate or delay development and economic growth depending on how it is structured in terms of decision-making. Good institutions have been known to promote economic growth in three major ways [15]: (a) they create environments conducive to protecting property rights; (b) they constrain the actions of the 'elite' (on the contrary, 'poor' institutions promote the vested interests of elites to the detriment of the majority); and (c), they provide the population with investment opportunities in economic activities. [16] and [17] provide empirical evidence to show that an economy with a good system of accountable government and a peaceful political terrain provides environment conducive to poverty reduction. On the side of growth, [18] and [19] demonstrate that government effectiveness positively and significantly affects Africa's economic growth, and one catalyst for economic growth is the existence of political institutions of limited government.

For [20] developing effective institutions in Sub-Saharan Africa (SSA) has been particularly complicated. Several impediments deter these institutions' efficiency. They include a proliferation of underdeveloped and ineffective institutions that make numerous African countries a high risk and unattractive environment for investors; poor political institutions that lead to economic mismanagement through kleptocratic dictatorships and political instability; weak social capital and social polarisation in SSA that prevents the intergroup cooperation necessary for economic development and leads to polarisation, which increases the risk of conflict; and finally, inadequate state capacity to reform or invest in institutions that promote economic development. Although not generalisable, [21] add another underlying reason, arguing that in developing countries public institutions often fail to provide services on an equal scale to all citizens, leading to what they call 'political marginalisation'. Abounding on this issue, they consider that areas with higher concentrations of marginalised citizens are likely not benefitting from the distribution of public goods. Political marginalisation usually occurs in areas with little influence in the political outcomes of democratic processes [21]. 


\subsection{International institutions' role in Global South VET initiatives}

Several international institutions, such as the UNESCO and UNICEF, have a long tradition of collaboration in education transformation and improvement in Global South countries Rather recently, an institution as the OECD, established initially as an instrument for increasing the development of advanced economies, has shown interest in educational improvement in developing countries. This institution promoted a strategy -the OECD skills strategy, launched in 2012 [22]- which provides a policy framework that guides countries on how to invest in skills for creating jobs and boosting economic growth, in the context of the global economic crisis. The main objective was to transform countries into internationally competitive high skills economies. In the policy framework of the OECD, education and training policies should contribute to these strategies by [22]: (a) developing the relevant skills for the knowledge economy; (b) incentivising the participation of inactive individuals in the labour market through retraining and up-skilling; and (c) fostering entrepreneurship and supporting employers in the creation of highly skilled jobs. Given the renewed global interest in the skills sector of the education and development field, and the scarcity of solid alternative policy frameworks at a global level, it is reasonable to expect that a substantial number of stakeholders, including donors and governments in developing countries, will use the OECD skills strategy as a policy guide [23].

The OECD skills strategy policy framework rests on the OECD's traditional economistic focus on education and the primacy of human capital orthodoxy [22], [23]. The central premise of human capital theory is that investment in education and training is a key driver of economic growth [24]-[26]. More education and training will contribute to the development of individuals' skills, which has been associated with both higher individual earnings and growing societal wealth [27]. It may be interesting to note that the Better Skills report makes repeated reference to the situation of jobs and skills in 'emerging economies' and 'middle income countries', which are cited more than fifteen times in the report [22]. The report also makes explicit reference to the situation in West, East and Central Africa [22]:41. The OECD skills strategy clearly sees skills as the key to tackling inequality and promoting social mobility because, 'investing in skills is far less costly, in the long run, than paying the price of poorer health, lower incomes, unemployment and social exclusion - all of which are closely tied to lower skills' [22]:18. Undoubtedly, from this perspective, these premises advocate for a wide development of VET initiatives.

\section{The Lens of Sustainability}

Most ICT sustainability issues in developing countries are related to ensuring the continuity of ICT projects, so as to develop ways in which to alleviate the challenges associated with the use of ICT [28]. Among the challenges faced by ICT initiatives in Global South countries are: limited access to infrastructure, limited formal education, insufficient training and capacity building, financial and political constraints, and social and cultural challenges [28]. Sustainability focusses on two views of analysis, that is, the sustainability of ongoing ICT access, independent of specific technologies 
or projects, and the sustainability of development results through ICT-enabled development -e.g., education, health, empowerment, etc. [29]. ICT sustainability can be categorised into social and cultural, institutional, economic, political, and technological sustainability, which should be developed harmoniously in order to promote the overall ICT project sustainability [29].

However, another side of sustainability, which has been explored less, is that related to the link between expectations and real professional opportunities for those involved in VET programmes. No policy framework on education policies can aspire to provide better welfare opportunities if it operates in a context of high unemployment rates and low-paid jobs [22], [23]. Additionally, problems in the supply of skills can be due to poor information on the needs of the market and/or to the low capacity of education and training systems to respond to these needs. An informed educational planning initiative would ensure that the supply of skills is sufficient, in terms of both quantity and quality, to meet the current and emerging needs of the markets. Even in the case that education systems cannot satisfy the needs of the local markets, the availability of this information would allow governments to develop their own strategy to attract talent from abroad. In a global knowledge economy, governments are not merely encouraged to facilitate internal mobility among local labour markets; importing skills and talent from outside the country is also seen as very effective solution for dealing with the skills-shortages of national economies [23]. In other words, developed countries can become the magnet economies for highly skilled jobs. It is under this perspective that it is worth applying the prism of sustainable education and learning over the big picture: is it fair to attract talented and skilled workers from developing countries towards magnet economies, thus possibly meaning that they will never contribute to the well-being of the communities which made the effort to provide them with those skills?

This question could shed new light to the view of the big picture or, alternatively, make it even more complex. A first matter of concern would arguably be the interest for lower income countries to spend their money in VET development policies knowing that a portion of skilled trainees would eventually leave their communities in seek of better opportunities in magnet economies. A second concern, just obviating the implications of the first one, is that the reality of the economy, contrary to what human capital theories would argue, is characterised by a rapid expansion of the global supply of skills and the incapability of the demand to follow this pace and to generate enough highly-skilled jobs for this highly skilled population. As a consequence of this imbalance between the supply and demand for skills, countries will need to deal with the social discontent produced by the false promise of education and skills, as well as the social problem of growing unemployment and underemployment among trained professionals. A final consideration under the prism of sustainability in education and training, with implications for the dominant paradigm, which advocates continuous economic growth, is that relating to the current 'productivist' model of development. This model influences the social-educational system downward, thus focusing educational policies towards the objectives of continuous economic growth, as if no other alternatives could be feasible and/or desirable. If, as it seems, this paradigm of continuous economic growth is accepted as 
the driving force for development and social welfare, then it is necessary to study its environmental repercussions. The investment and use of information technology has potentially negative environmental implications. These implications need to be addressed if the well-being of future generations is not to be compromised. The type and magnitude of the negative impacts of ICT on the environment should also be studied from the perspective of sustainability. Consequently, policies aimed at minimising environmental damage ought to be developed in parallel with VET initiatives.

\section{$4 \quad$ Recommended Courses of Action}

As stated at the beginning of this paper, no easy solution can be provided for improving the development and effective success of VET initiatives in ICT in Global South countries. To pretend such a task would, very likely, only lead to symptomatic solutions, thus deferring the design and implementation of structural solutions with long-term beneficial outputs. Instead, some general guidelines to address root problems -proposed by various researchers- are summarised below; an integrated view might be the key to start unrevealing the big picture.

Regarding the ICT utopia in education, [3]:723 argues that for educational technology to have an impact in classrooms as dramatic as it has been credited with having on the streets, through social networking, a more fundamental shift in thinking about education is required. The development of the 21st Century skills for employability that the youth of today are said to need in order to succeed in a globalised employment marketplace will not be achieved simply by more or less successful computer hardware distribution strategies and improved connectivity in schools. [11] summarise the lessons learned from the UNICEF's Child-Friendly Technology Framework programme in eleven countries around sub-Saharan Africa and offer some best practices guidelines: (a) Don't Get Distracted by Devices or Upgrades: with the goal of moving away from technology as the focus of improvements in education, emphasising rather the importance of well-designed user experiences as the key to holding stakeholder's attention and engagement into the learning process; (b) Offline, No-tech Activities are a Critical Foundation for Technology Initiative Success: for every lesson and every step in curricular progression, there should be a complimentary robust offline component, which can be completed when the infrastructure is non-cooperative or available; (c) Always Consider the Teacher as a Primary Beneficiary: the experience of UNICEF's ChildFriendly Technology Framework showed that teachers were the hinge upon which programme success was leveraged; (d) Partners Create Sustainability: a way to highlight the benefits of promoting collaboration or support from NGOs, local governments and companies so as to succeed in connecting classroom initiatives, thus fostering long term collaboration; (e) Budget Yourself Out of Business, with the aim of including the wider community as actors that can collaborate in generating connections, prompting students to reach out for resources even in the case of 
educational funding ends; and (f) Monitoring and Evaluation, in order to better adjust the scarce resources to enhance field demands.

As regards the problems derived from the need to develop effective institutions, [30] argue for adopting a microeconomic approach that explicitly takes political and bureaucratic incentives and constraints into account. Such an approach can provide a fruitful, and complementary, way forward. They conclude that innovations in the measurement of performance and ability in education and health open up ways to influence the political economic equilibrium. A number of researchers have pointed out some institutional ingredients that can contribute to accelerating the effectiveness of Institutions to foster economic growth. Among them, well-defined property rights [31], the effectiveness of interest groupings [32], political stability and credibility [33], control of corruption [34], regulatory and bureaucratic quality [35], avoidance of the coexistence between weak institutions and powerful industrial groups [36], strong and adequate political institutions [37], and [38] the illustration that the investment rate is positively correlated with per capita GDP growth when accountability is taken into account.

Under the vision of VET programmes as a means to develop skills in the workforce, the OECD skills strategy [22] stresses that investing in skills is just the first step; successful skills policies also need to ensure that available skills are used effectively so that no investment is wasted. Despite the fact that in the short term a 'skills surplus' may develop, in the long term investing in the skills supply will always pay off because it can help to transform the kinds of employment on offer in such economies, as employers can more easily recruit skilled workers who, in turn, improve the quality of the work that they do.

\section{$5 \quad$ Final Thoughts}

At first glance, taking into consideration the contributions of the academic community, it could be argued that a developing country, with good institutional quality and good regulations, lack of corruption, good intellectual property laws, a stable democracy and/or rule of law, etc., would be able to attract internal or external investments in educational ICT and, coupled with good government policies including the promotion of VET initiatives-, could eventually lead to technology readiness and a high level of professional ICT usage. From this point on, there can also be a direct relationship between ICT development and levels of human development and economic growth. However, this apparently straightforward route map, has demonstrated that it does not adhere to any simple or fluid set of activities. In any case, under the hypothesis of Global South countries having developed their full capacity to promote effective educational, and consequently, VET initiatives, the challenge of sustainability as a complex issue surrounding any model of vocational education and training for development still remains.

Far from the neoliberal imaginary with which policies from the Global North are imbued, as a prospective conclusion about the ITC utopia in Global south countries, it could be stated that for promoting the development of twenty-first-century skills 
amongst students, the strength of local traditions and social-economic status are of much greater importance. The recognition that the problem is not (only) in the supply of skills, implies that education systems cannot address skills problems alone and a more coordinated national strategy is needed. Furthermore, as [39] argued, there is still no workable model of vocational education and training for development. As a final point of consideration, it could be worth stressing that most of the above discussion focuses on topics and concerns that have little to do with engagement in debates about skills for sustainable production and consumption.

\section{References}

1. M. Warschauer and T. Matuchniak, "New Technology and Digital Worlds: Analyzing Evidence of Equity in Access, Use, and Outcomes,” Rev. Res. Educ., vol. 34, no. 1, pp. 179-225, Mar. 2010.

2. C. B. Jensen and P. Lauritsen, "Reading digital denmark: IT reports as material-semiotic actors," Sci. Technol. Hum. Values, 2005.

3. M. Lightfoot, "Education reform for the knowledge economy in the state of Sangon," Compare, vol. 45, no. 5, pp. 705-726, 2015.

4. N. Law, W. J. Pelgrum, and T. Plomp, Pedagogy and ICT use in schools around the world: Findings from the IEA SITES 2006 study. 2008.

5. R. Sutherland et al., "Transforming teaching and learning: Embedding ICT into everyday classroom practices,” J. Comput. Assist. Learn., 2004.

6. M. W. Apple, “Are We Wasting Money on Computers in Schools?,” Educ. Policy, 2004.

7. L. Cuban, New Technologies in Old Universities. 2001.

8. T. Monahan, Globalization, Technological Change, and Public Education, 1st ed. New York : Routledge , 2005.

9. R. Stamboliyska, "Information technologies and education in the Arab World," Nat. Middle East, 2013.

10. N. Selwyn, Education in a digital world: Global perspectives on technology and education. 2012.

11. E. Calhoun and N. Calhoun, "Using Technology to Shift Education Paradigms in LowResource Environments,” Stab. Int. J. Secur. Dev., vol. 3, no. 1, p. 21, 2014.

12. E. Thibeault, "Décryptage de l' usage des TIC au Burkina-Faso et en République démocratique du Congo Accès, pratiques et compétences des étudiants ICT' s use a alysis i Bu ki a -Faso and Democratic Republic of Congo Access , practices and students competences,” no. Ea 4071, pp. 1-20, 2013.

13. F. O. Bankole and L. Mimbi, "ICT Infrastructure and It's Impact on National Development: A Research Direction for Africa,” African J. Inf. Syst., vol. 9, no. 2, p. 77, 2017.

14. J. M. Luiz, "Institutions and economic performance: Implications for African development,” J. Int. Dev., 2009.

15. D. Acemoglu and J. A. Robinson, Why Nations Fail: The Origins of Power, Prosperity and Poverty, 1st ed. New York: Crown, 2012.

16. A. Chong and C. Calderón, "Causality and feedback between institutional measures and economic growth,” Econ. Polit., 2000.

17. E. Tebaldi and R. Mohan, "Institutions and poverty,” J. Dev. Stud., 2010.

18. J. C. Anyanwu, "Factors affecting economic growth in Africa: Are there any lessons from China?,” African Dev. Rev., 2014.

19. A. G. Mijiyawa, "Africa's recent economic growth: What are the contributing factors?," African Dev. Rev., 2013. 
20. D. K. Manda and S. Mwakubo, "Institutions and service delivery in Africa: An overview,” J. Afr. Econ., vol. 22, no. SUPPLEMENT2, pp. 4-15, 2013.

21. M. P. Blimpo, R. Harding, and L. Wantchekon, "Public Investment in Rural Infrastructure: Some Political Economy Considerations,” J. Afr. Econ., vol. 22, no. suppl 2, pp. ii57-ii83, Aug. 2013.

22. OECD, Better Skills, Better Jobs, Better Lives A Strategic Approach to Skills Policies. 2012.

23. O. Valiente, “The OECD skills strategy and the education agenda for development," Int. J. Educ. Dev., 2014.

24. T. W. Schultz, "Invest in Human Capital," Amercian Econ. Rev. Vol. 51, 1961.

25. E. F. Denison, "SOURCES OF POSTWAR GROWTH IN NINE WESTERN COUNTRIES.,” Am. Econ. Rev., 1967.

26. G. S. Becker, "Human Capital: The concise encyclopedia of economics," Columbia, New York. 1964.

27. E. A. Hanushek and L. Woessmann, "Do better schools lead to more growth? Cognitive skills, economic outcomes, and causation,” J. Econ. Growth, 2012.

28. C. Pade-Khene, B. Mallinson, and D. Sewry, "Sustainable rural ICT project management practice for developing countries: Investigating the Dwesa and RUMEP projects," Inf. Technol. Dev., vol. 17, no. 3, pp. 187-212, 2011.

29. O. Hietanen, "Indicators of sustainable development," Futura, vol. 21, no. 2, pp. 6-7, 2002.

30. T. Bold and J. Svensson, "Policies and Institutions for Effective Service Delivery: The Need of a Microeconomic and Micropolitical Approach,” J. Afr. Econ., vol. 22, no. suppl 2, pp. ii16-ii38, Aug. 2013.

31. S. Knack and P. Keefer, "Institutions And Economic Performance: Cross-Country Tests Using Alternative Institutional Measures,” Econ. Polit., 1995.

32. M. Olson, The Rise and Decline of Nations: Economic Growth, Stagflation, and Social Rigidities. Yale University Press, 2008.

33. R. J. Barro, "Economic Growth in a Cross-section of Nations,” Q. J. Econ., 1991.

34. Paolo Mauro, “Corruption and Growth,” Q. J. Econ., 1995.

35. P. Keefer and S. Knack, "Why don't poor countries catch up? A cross-national test of an institutional explanation,” Econ. Inq., 1997.

36. P. R. Lane and A. Tornell, "Power, Growth, and the Voracity Effect," J. Econ. Growth, 1996.

37. M. Nissanke and E. Thorbecke, "Introduction: Globalization-Poverty Channels and Case Studies from Sub-Saharan Africa," African Dev. Rev., 2008.

38. A. Diop, G. Dufrénot, and G. Sanon, "Is per capita growth in Africa Hampered by poor governance and weak institutions? An empirical study on the ECOWAS countries," African Dev. Rev., 2010.

39. S. McGrath, "Vocational education and training for development: A policy in need of a theory?,” Int. J. Educ. Dev., vol. 32, no. 5, pp. 623-631, 2012. 